\title{
Peran Budaya Organisasi terhadap Disiplin Kerja Karyawan Direktorat Produksi PT Krakatau Steel (Persero) Tbk Cilegon
}

\author{
Muhammad Luhung Pribadi, Benny Herlena \\ Universitas Islam Negeri Sunan Kalijaga, Yogyakarta \\ e-mail: luhung76@gmail.com
}

\begin{abstract}
This research aims to study the effect of organizational culture toward employee work discipline at Directorate Production PT Krakatau Steel (Persero) Tbk Cilegon. The subjects of this research are 115 employees from several divisions at Directorate Production of PT Krakatau Steel (Persero) Tbk Cilegon. The data were collected through cluster sampling technique. Instrument used are organizational culture scale, and work discipline scale. Data were analized using correlational test regression analysis technique. The result show that there is significant correlation of organizational culture for employee work discipline at Directorate Production PT Krakatau Steel (Persero) Tbk Cilegon. It is shown by correlation coefficient of regression analysis as $R=0,534$, with effective contribution $R$ square $\left(R^{2}\right)=0,285$ or $28,5 \%$, and significance level $p=0,000$. Thus, it proves the hypothesis in this research is accepted.
\end{abstract}

Keywords: organizational culture, work discipline, employee

\begin{abstract}
Abstrak
Penelitian ini bertujuan untuk melihat pengaruh budaya organisasi pada disiplin kerja para karyawan PT Krakatau Steel (Persero) Tbk Cilegon. Subjek penelitian adalah 115 karyawan dari berbagai divisi pada direktorat produksi. Pengumpulan data dilakukan dengan teknik cluster sampling. Subjek penelitian mengisi skala budaya organisasi dan skala kedisiplinan kerja. Selanjutnya data dianalisa menggunakan uji regresi. Hasil penelitian menunjukkan adanya hubungan yang signifikan antara budaya organisasi dengan kedisiplinan kerja pada karyawan di direktorat produksi PT Krakatau Steel (Persero) Tbk Cilegon. Koefisien korelasi yang didapatkan dari analisis regresi yang dilakukan adalah $\mathrm{R}=0,534$, dngan nilai $\mathrm{R}$ square $\left(\mathrm{R}^{2}\right)=0,285$ or $28,5 \%$, dengan taraf signifikansi $\mathrm{p}=0,000$. Dengan kata lain, hipotesis penelitian ini diterima.
\end{abstract}

Kata kunci: budaya organisasi, kedisiplinan kerja, karyawan

\section{Pendahuluan}

Dunia industri dan organisasi saat ini bergerak dinamis, berbagai peristiwa dan fenomena terkait industri dan organisasi dapat dijumpai di berbagai perusahaan dan institusi. Perusahaan dengan berbagai produk dan layanannya berusaha untuk bergerak menuju iklim persaingan yang makin kompetitif. Saat ini dunia industri dan organisasi di Indonesia telah memasuki babak baru dalam pasar industri dan ekonomi global yang ditandai dengan disepakatinya AFTA (ASEAN Free Trade Area) dan MEA (Masyarakat Ekonomi ASEAN) oleh pemerintah di akhir tahun 2014 lalu. Kesepakatan pasar ekonomi
ASEAN tersebut menjadikan Indonesia harus siap menghadapi pasar industri dan ekonomi global dan kompetitif yang melibatkan negara-negara anggota ASEAN (Kompas, 2015).

Berbicara mengenai persaingan yang kompetitif dalam dunia industri dan organisasi, sumber daya manusia merupakan suatu unsur yang sangat penting dalam menentukan maju atau tidaknya suatu perusahaan. Sumber daya manusia (SDM) dalam perusahaan berupa tenaga kerja yang baik akan mampu menyesuaikan diri dengan kondisi per-saingan yang kompetitif sehingga mereka mampu bertahan dan memajukan perusahaan. 
Sumber daya manusia dalam perusahaan harus memiliki beberapa unsur sehingga tenaga kerja tersebut dapat dikatakan sebagai tenga kerja atau SDM yang berkualitas. Schultz mengemukakan bahwa faktor yang menentukan kualitas tenaga kerja adalah tingkat kecerdasan, bakat, sifat kepribadian seseorang, tingkat pendidikan, etos kerja, dan disiplin kerja (Helmi, 1996).

\section{Disiplin Kerja}

Robbins menjelaskan disiplin kerja adalah suatu kepatuhan dalam menjalankan pekerjaan sesuai dengan aturan dan standar perusahaan (Franklin \& Pagan, 2006). Selanjutnya, disiplin kerja merupakan sikap dan perilaku seseorang untuk mematuhi peraturan organisasi yang didasarkan atas kesadaran diri untuk menyesuaikan dengan aturan dan standar organisasi (Helmi, 1996). Hal tersebut menunjukkan bahwa disiplin kerja tidak hanya patuh dan taat terhadap tata tertib maupun aturan, namun juga mampu bekerja sesuai dengan standar yang ditetapkan perusahaan.

Disiplin merupakan suatu perilaku yang konsisten yang dilakukan secara berulang sehingga terbentuk suatu pola kebiasaan. Perilaku dan kebiasaan yang terpola tersebut kemudian membentuk suatu budaya. Suatu pola perilaku atau kebiasaan kerja yang dibudayakan dalam suatu organisasi disebut budaya organisasi. Budaya organisasi merupakan nilai-nilai, prinsip, tradisi dan cara-cara bekerja yang dianut bersama oleh para anggota organisasi dan memengaruhi cara mereka bertindak (Robbins, 2010). Budaya organisasi memberikan identitas pada anggotanya untuk berperilaku sesuai prinsip dan nilai organisasi. Apabila prinsip dan nilai perusahaan dapat dimaknai dan dipahami anggota organisasi dengan baik dan benar, maka akan terwujud perilaku yang sejalan dengan prinsip nilai organisasi, sehingga muncul perilaku disiplin kerja yang baik pada anggota organisasi.

Disiplin kerja menurut penjelasan Prijodarminto (1993) merupakan kondisi yang tercipta melalui proses serangkaian perilaku yang menunjukkan kesediaan untuk taat, patuh dan tertib terhadap peraturan. Hal tersebut menjelaskan bahwa disiplin kerja merupakan suatu rangkaian perilaku yang terbentuk dari sikap mental seseorang. Sikap mental tersebut terwujud melalui kesediaan seseorang untuk patuh dan taat terhadap peraturan, tata tertib, dan bekerja sesuai standar perusahan. Disiplin kerja yang dikemukakan oleh Prijodarminto (1993) di atas, terdiri dari tiga aspek, yaitu sikap mental, pemahaman yang baik mengenai sistem maupun aturan, dan sikap berperilaku dalam bekerja.

Adapun menurut Guffey dan Helms (2001), disiplin kerja merupakan proses seseorang dalam mengontrol perilaku dalam menaati aturan dan upaya dalam meningkatkan kualitas kerja. Proses dalam diri seseorang dalam mewujudkan sikap dan perilaku disiplin melibatkan proses pemahaman terhadap peraturan yang ditetapkan perusahaan dan bekerja sesuai dengan standar-standar yang telah ditetapkan oleh perusahaan. Berdasar uraian tersebut dapat peneliti simpulkan disiplin kerja adalah perilaku konsisten yang menunjukkan kesediaan untuk taat dan patuh secara tertib terhadap peraturan sebagai upaya meningkatkan kualitas dan kinerja.

Selanjutnya, Helmi (1996) menjelaskan bahwa faktor kepribadian dan lingkungan merupakan faktor-faktor yang memengaruhi disiplin kerja seseorang. Kepribadian adalah faktor yang berasal dari sistem nilai yang ada dan diyakini dalam diri sebagai acuan bersikap dan berperilaku, sedangkan faktor lingkungan berasal dari proses belajar yang dilakukan dari lingkungan kerja salah satunya adalah melalui budaya organisasi. 


\section{Budaya Organisasi}

Schein (2004) mengartikan budaya organisasi merupakan suatu pola asumsi yang dipelajari organisasi dalam menyelesaikan permasalahan terkait adaptasi terhadap lingkungan eksternal organisasi dan integrasi internal antar unitunit organisasi. Budaya organisasi terdiri dari dimensi lapisan bertingkat yaitu lapisan terlihat atau visible artifacts dan lapisan tak terlihat atau invicible artifacts (Daft, 2010). Invisible artifacts dalam dimensi budaya organisasi merupakan suatu sistem nilai yang berperan dalam terbentuknya sikap dan perilaku anggota organisasi. Hal tersebut dikarenakan sistem nilai merupakan wujud dari nilai-nilai pokok suatu organisasi yang mengarahkan anggota organisasi mewujudkan goal, visi, misi dan tujuannya (Schein, 2004). Hal tersebut artinya bahwa sistem nilai merupakan nilai-nilai pokok organisasi yang diyakini anggota organisasi sehingga mengarahkan anggota organisasi untuk bekerja sesuai peraturan dan standar perusahaan. Sikap dan perilaku seseorang yang bekerja sesuai standar perusahaan dan mematuhi peraturan merupakan wujud dari sikap dan perilaku disiplin kerja.

Robbins (2010) menjelaskan budaya organisasi merupakan nilai-nilai, prinsip, tradisi dan cara-cara bekerja yang dianut bersama oleh para anggota organisasi dan memengaruhi cara mereka bertindak. Budaya organisasi terdiri dari nilai-nilai dominan yang didukung oleh organisasi atau falsafah yang menuntun kebijaksanaan organisasi terhadap pegawai dan pelanggaran, atau cara pekerjaan yang dilakukan di tempat kerja, serta asumsi maupun kepercayaan yang terdapat pada anggota organisasi.

Budaya organisasi PT Krakatau Steel (Persero) berpedoman pada corporate values perusahaan yaitu competence, integrity, reliable dan innovative sebagai implementasi visi dan misi perusahaan yang tercermin dalam berbagai sistemsistem organisasi maupun aktifitas karyawan dalam perusahaan (PT Krakatau Steel, 2009). Sehubungan dengan hal tersebut, Denison dan Mishra (1995) mengemukakan dalam penelitiannya bahwa budaya organisasi memberikan suatu identitas pada anggota organisasinya sebagai bagian dari organisasi. Budaya organisasi akan membentuk suatu values, pola pikir dan kebiasaan yang tidak bersifat individual. Hal tersebut membentuk perilaku yang mengarahkan seseorang mampu beradaptasi untuk bekerja secara efektif sesuai dengan standar perusahaan, dan memberikan identitas yang kuat secara kolektif pada anggota organisasi. Hasil penelitian tersebut menunjukkan bahwa budaya organisasi membentuk values, pola pikir dan kebiasaan kolektif sehingga mengarahkan seseorang untuk bekerja sesuai standar perusahaan yang merupakan bentuk dari salah satu sikap dan perilaku disiplin.

Penelitian sebelumnya yang dilakukan Brahmasari (2009) mengenai hubungan budaya organisasi dan disiplin kerja menunjukkan bahwa budaya organisasi yang diterapkan oleh karyawan memberikan pengaruh terhadap meningkatnya sikap dan perilaku disiplin kerja karyawan. Dalam penelitiannya tersebut dijelaskan bahwa budaya organisasi yang terdiri dari nilai-nilai dan implementasi dari visi misi perusahaan yang diterapkan karyawan memberikan pengaruh terhadap meningkatnya disiplin kerja dan kinerja karyawan.

Berdasarkan penjelasan mengenai penerapan budaya organisasi PT Krakatau Steel (Persero) Tbk yang ditinjau maupun diperkuat dari penelitian-penelitian sebelumnya, dapat disimpulkan bahwa budaya organisasi memiliki peran dalam terbentuknya disiplin kerja. Hal tersebut dapat dijelaskan bahwa dimensi budaya organisasi terdiri dari sistem nilai (values) yang membentuk keyakinan dalam diri seseorang. Adapun budaya organisasi PT Krakatau Steel (Persero) Tbk berpedoman pada corporate values perusahaan sebagai 
sistem nilai budaya organisasi. Corporate values merupakan pedoman implementasi budaya organisasi yang berperan dalam memunculkan sikap dan perilaku disiplin kerja, dimana corporate values perusahaan menjadi acuan karyawan untuk bersikap dan berperilaku disiplin. Selain itu, corporate values berfungsi sebagai mekanisme kontrol sikap dan perilaku anggota organisasi sehingga penerapan budaya organisasi yang dilakukan perusahaan memiliki peran dalam mengarahkan anggotanya untuk bersikap dan berperilaku disiplin.

Berdasarkan penjelasan tersebut, hipotesis yang diajukan dalam penelitian ini adalah: "Ada peran budaya organisasi terhadap kedisiplinan kerja karyawan.”

\section{Metode Penelitian}

Subjek dalam penelitian ini adalah karyawan PT Krakatau Steel (Persero) Tbk Cilegon sejumlah 115 orang, yang berasal dari berbagai divisi di Direktorat Produksi. Pengambilan data sampel terkait subjek pada penelitian ini dilakukan dengan teknik cluster sampling di beberapa divisi kerja Direktorat Produksi PT Krakatau Steel (Persero) Tbk Cilegon berdasarkan kriteria penelitian sebagai berikut: subjek merupakan karyawan tetap PT Krakatau Steel (Persero) Tbk, subjek merupakan karyawan reguler non-shift.

Variabel tergantung dalam penelitian ini adalah disiplin kerja, sedangkan variabel bebas penelitian adalah budaya organisasi. Instrumen yang digunakan pada penelitian ini yaitu skala disiplin kerja, dan skala budaya organisasi. Disiplin kerja diukur dengan menggunakan skala disiplin kerja yang disusun berdasarkan aspekaspek disiplin kerja yang dikemukakan oleh Prijodarminto (1993) yaitu: sikap mental, pemahaman yang baik terhadap sistem, peraturan maupun norma yang berlaku, dan sikap berperilaku karyawan dalam bekerja. Adapun budaya organisasi diukur menggunakan skala budaya organisasi yang disusun berdasarkan pedoman budaya organisasi PT Krakatau Steel (Persero) Tbk yang mengacu pada corporate values perusahaan yaitu compentence, integrity, reliable dan innovative (PT Krakatau Steel, 2009).

Data penelitian yang diperoleh pada penelitian ini kemudian di uji dengan menggunakan teknik analisis regresi. Uji hubungan dengan teknik analisis regresi tersebut dilakukan dengan menggunakan software SPSS ver.16 for Windows.

\section{Hasil Penelitian dan Pembahasan}

Hasil dari penelitian menunjukkan budaya organisasi memiliki peran terhadap kedisiplinan kerja karyawan Direktorat Produksi PT Krakatau Steel (Persero) Tbk Cilegon. Hal tersebut ditunjukkan melalui koefisien korelasi (R) sebesar 0,534 dengan nilai $\mathrm{p}=0,000$. Nilai signifikansi dalam penelitian ini ditunjukkan berdasarkan nilai $\mathrm{p}=0,000$ dimana kaidah signifikansi $\mathrm{p}<0,05$. Hasil penelitian yang signifikan tersebut menyatakan bahwa hipotesis yang diajukan dalam penelitian ini diterima.

Adapun hasil dari pengujian hipo-tesis penelitian tersebut menunjukkan bahwa nilai-nilai budaya organisasi berperan terhadap terbentuknya disiplin kerja karyawan. Robbins menjelaskan disiplin kerja adalah suatu kepatuhan dalam menjalankan pekerjaan sesuai dengan aturan dan standar perusahaan (Franklin \& Pagan, 2006). Sikap dan perilaku tersebut merupakan kebiasaan yang terbentuk dari nilai-nilai yang dihayati seseorang dari nilai-nilai organi-sasinya, maupun lingkungannya. Nilai-nilai yang dihayati seseorang yang berasal dari organisasinya disebut nilai-nilai budaya organisasi. Nilai budaya organisasi berperan dalam terbentuknya kedisiplinan karyawan, dimana nilai-nilai budaya organisasi akan mengarahkan seseorang dalam bersikap dan berperilaku disiplin. Hasil pengujian hipotesis dalam penelitian ini menunjukkan bahwa penerapan budaya organisasi yang dilakukan oleh PT Krakatau Steel 
(Persero) Tbk, memberikan peran terhadap kedisiplinan kerja karyawan. Penerapan budaya organisasi yang dilakukan perusahaan mengarahkan karyawan untuk bersikap dan berperilaku disiplin sesuai dengan aturan maupun kriteria yang ditetapkan oleh perusahaan.

Temuan hasil penelitian ini sejalan dengan beberapa penelitian sebelumnya yang dilakukan oleh Brahmasari (2009) tentang hubungan budaya organisasi terhadap disiplin kerja karyawan. Hasil penelitian tersebut menunjukkan bahwa budaya organisasi yang diterapkan oleh karyawan memberikan pengaruh terhadap meningkatnya sikap dan perilaku disiplin kerja karyawan. Berdasarkan hasil penelitiannya tersebut dijelaskan bahwa budaya organisasi terdiri dari nilai-nilai dan implementasi dari visi misi perusahaan. Budaya organisasi yang diterapkan karyawan tersebut memberikan pengaruh terhadap meningkatnya disiplin kerja dan kinerja karyawan.

Hasil dalam penelitian ini pun sejalan dengan penelitian lainnya yang dilakukan oleh Denison dan Mishra (1995) tentang budaya organisasi, performa kerja dan kualitas karyawan. Penelitian tersebut menunjukkan bahwa budaya organisasi berpengaruh kepada performa perusahaan dan kualitas karyawan. Budaya organisasi memberikan suatu identitas kepada individu sebagai bagian dari organisasi. Selanjutnya, budaya organisasi akan membentuk suatu values, pola pikir dan kebiasaan yang tidak bersifat individual. Hal tersebut membentuk perilaku yang mengarahkan seseorang mampu beradaptasi untuk bekerja secara efektif sesuai dengan standar perusahaan, dan memberikan identitas yang kuat secara kolektif pada anggota organisasi. Hasil penelitian tersebut menunjukkan bahwa budaya organisasi membentuk values, pola pikir dan kebiasaan kolektif sehingga mengarahkan seseorang untuk bekerja sesuai standar perusahaan yang salah satunya ialah sikap dan perilaku disiplin dalam bekerja.

Berdasarkan penelitian yang dilakukan terhadap disiplin kerja pada karyawan Direktorat Produksi PT Krakatau Steel (Persero) Tbk Cilegon sebagai subjek penelitian ini, menunjukkan bahwa sejumlah $21,74 \%$ subjek penelitian tergolong dalam kategori tinggi tingkat disiplin kerjanya. Sejumlah 39,13\% subjek penelitian tergolong dalam kategori sedang tingkat disiplin kerjanya. Sejumlah 31,30\% subjek penelitian tergolong dalam kategori disiplin kerja yang masih belum sesuai standar yang ditetapkan perusahaan. Adapun untuk subjek yang tergolong dalam disiplin kerja kategori yang sangat tinggi adalah sejumlah 5,21\%, dan masih terdapat $2,6 \%$ subjek tergolong dalam kategori disiplin kerja dibawah kriteria minimum yang ditetapkan oleh perusahaan. Hasil penelitian tersebut menunjukkan bahwa sebagian besar subjek penelitian ini (sekitar 66.08\%) yaitu karyawan Direktorat Produksi PT Krakatau Steel (Persero) Tbk Cilegon memiliki disiplin kerja yang cukup baik. Namun demikian, masih terdapat karyawan di Direktorat Produksi PT Krakatau Steel (Persero) Tbk Cilegon tersebut yang masih memiliki tingkat disiplin kerja dalam kategori yang belum sesuai dengan target perusahaan.

Disiplin kerja merupakan suatu sikap dan perilaku yang terwujud melalui kebiasaan yang melekat pada diri seseorang. Kebiasaan sikap dan perilaku dapat melekat pada diri seseorang melalui pemahaman lingkungannya maupun pemahaman terhadap nilai-nilai organisasi. Sehubungan dengan hal tersebut, dapat dijelaskan bahwa budaya organisasi yang terdiri dari sistem nilai (values) merupakan nilai-nilai dan falsafah sebagai pedoman berperilaku dalam suatu organisasi (Schein, 2004). Sistem nilai yang telah terbentuk tersebut secara umum berupa core values organisasi. Pada kancah penelitian ini, core values organisasi tersebut diwujudkan 
dalam bentuk corporate values. Corporate values yang dimiliki dijadikan dan digunakan sebagai pedoman dalam implementasi budaya organisasi di perusahaan.

Penerapan Corporate values sebagai implementasi budaya organisasi yang dilakukan oleh perusahaan akan menjadi indikator yang menunjukkan seberapa sesuai karyawan berperilaku terhadap visi dan misi perusahaan. Sikap dan perilaku karyawan yang sesuai dengan visi dan misi perusahaan salah satunya diwujudkan dalam sikap dan perilaku disiplin kerja. Penjelasan tersebut menunjukkan bahwa tinggi rendahnya kedisiplinan kerja karyawan dalam suatu perusahaan terkait dengan penerapan nilai-nilai budaya organasasi yang diterapkan karyawan pada aktivitas kerja. Terkait hal tersebut, budaya organisasi yang diterapkan oleh PT Krakatau Steel (Persero) Tbk berpedoman pada corporate values perusahaan, akan mengarahkan sikap dan perilaku karyawan sesuai dengan visi, misi dan tujuan perusahaan. Selanjutnya, hal tersebut dapat diartikan bahwa tinggi dan rendahnya penerapan corporate values perusahaan yang dilakukan oleh karyawan PT Krakatau Steel (Persero) Tbk, akan memberikan pengaruh terhadap tinggi rendahnya kedisiplinan kerja karyawan.

Terkait dengan temuan pada penelitian ini, tentang masih terdapat sekitar $31,30 \%$ karyawan yang juga sebagai subjek penelitian ini tergolong dalam kategori disiplin kerja yang masih belum sesuai standar yang ditetapkan perusahaan. Hal demikian sebagaimana dikemukakan oleh Robbins (2010) bahwa corporate culture atau budaya organisasi yang ada pada suatu organisasi menunjukkan bagaimana persepsi karyawan terhadap karakteristik organisasi. Terdapat dua karakteristik budaya organisasi yaitu strong culture dan weak culture. Budaya organisasi dengan tipikal strong culture mampu mendistribusikan core values organisasi secara luas dan merata pada setiap bagian dari perusahaan atau organisasi sehingga mampu mengarahkan sikap dan perilaku karyawan untuk sejalan dengan core values organisasi. Sebaliknya, tipikal weak culture pada organisasi menunjukkan bahwa budaya organisasi perusahaan tidak terdistribusi secara merata sehingga muncul beberapa perilaku yang belum atau tidak sejalan dengan core values organisasi.

Berkaitan dengan penjelasan tersebut, pada subyek penelitian ditemukan sebagian besar karyawan telah menunjukkan disiplin kerja yang cukup baik. Namun demikian sebagian lainnya masih tegolong pada kategori disiplin kerja yang belum sesuai dengan harapan perusahaan. Menurut Robbins (2010), bahwa disiplin kerja yang cenderung masih belum sesuai dengan harapan organisasi menunjukkan bahwa karyawan belum sepenuhnya menyerap dan menerapkan core values organisasi. Hal tersebut memberikan indikasi bahwa masih tampak terjadi kriteria weak culture pada sebagian karyawan yang belum sepenuhnya menyerap dan menerapkan core values organisasi, sehingga berdampak pada tingkat disiplin kerja mereka.

Penerapan budaya organisasi pada PT Krakatau Steel (Persero) Tbk berpedoman pada corporate values perusahaan yaitu Competence, Integrity, Reliable dan Innovative (PT Krakatau Steel, 2009). Makna Corporate values Competence yaitu kepercayaan akan kemampuan serta semangat untuk meningkatkan pengetahuan, keterampilan dan keahlian, dan sikap metal demi peningkatan kinerja yang berkesinambungan. Selanjutnya, makna corporate values dari Integrity ialah komitmen yang tinggi terhadap setiap kesepakatan, aturan dan ketentuan serta undang-undang yang berlaku melalui loyalitas profesi dalam memperjuangkan kepentingan perusahaan. Makna corporate values dari Reliable mencerminkan kesiapan, kecepatan dan tanggap merespon komitmen dan janji, dengan mensinergikan berbagai kemampuan untuk meningkatkan kepuasan dan kepercayaan pelanggan. 
Adapun makna corporate values dari Innovative ialah kemauan dan kemampuan untuk menciptakan gagasan baru dan implementasi yang lebih baik dalam memperbaiki kualitas proses dan hasil kerja di atas standar yang ditetapkan. Corporate values tersebut tercermin dalam berbagai sistem-sistem organisasi yang membentuk aktifitas karyawan dalam perusahaan.

Hasil penelitian yang dilakukan terkait penerapan budaya organisasi PT Krakatau Steel (Persero) Tbk Cilegon pada karyawan Direktorat Produksi sebagai subjek penelitian menunjukkan bahwa subjek penelitian terbanyak tergolong pada kategori sedang yaitu sebesar 43,48\%. Adapun subjek penelitian yang tergolong pada kategori rendah yaitu sebesar 27,83\% dan kategori tinggi dalam penerapan budaya organisasi perusahaan yaitu sebesar $20,87 \%$. Selebihnya, sebesar 5,21\% subjek penelitian merupakan kategori sangat rendah dan $2,61 \%$ dalam kategori sangat tinggi dalam penerapan budaya organisasi perusahaan. Hasil penelitian tersebut menunjukkan bahwa sebagian besar karyawan Direktorat Produksi PT Krakatau Steel (Persero) Tbk Cilegon telah cukup baik dalam menerapkan budaya organisasi perusahaan dalam aktivitas perusahaan. Namun demikian, masih banyak pula karyawan Direktorat Produksi yang masih kurang baik dalam menerapkan budaya perusahaan.

Pengujian hipotesis yang dilakukan dengan analisis regresi menunjukkan bahwa budaya organisasi sebagai prediktor memberi peran yang signifikan terhadap disiplin kerja. Hal tersebut ditunjukkan pada koefisien regresi pada standardized coefficients beta sebesar 0,534 dengan taraf signifikansi $0,000(\mathrm{p}<0,05)$. Nilai tersebut menunjukkan bahwa koefisien regresi bernilai positif. Hasil pengujian hipotesis tersebut menunjukkan bahwa semakin besar budaya organisasi yang diterapkan karyawan akan memberikan peran pada disiplin kerja karyawan yang semakin baik. Penerapan budaya organisasi
PT Krakatau Steel (Persero) Tbk yang dilakukan melalui implementasi corporate values dalam aktivitas kerja karyawan berperan dalam membentuk disiplin kerja karyawan yang baik.

Berdasarkan penjelasan hasil penelitian di atas, dapat disimpulkan bahwa budaya organisasi memiliki peran terhadap kedisiplinan kerja. Budaya organisasi berperan secara signifikan terhadap disiplin kerja karyawan, dimana budaya organisasi yang diterapkan secara baik oleh karyawan dapat meningkatkan disiplin kerja karyawan. Hasil dari analisis regresi menunjukkan bahwa nilai $R$ Square $\left(\mathrm{R}^{2}\right)$ sebesar 0,285 atau $28,5 \%$ artinya variabel prediktor memberikan sumbangan efektif kepada disiplin kerja karyawan sebesar 28,5 \%. Hal tersebut menunjukkan bahwa terdapat $71,5 \%$ sumbangan efektif dari faktor lainnya atau berasal dari variabel lainnya yang belum teridentifikasi dalam penelitian ini.

\section{Simpulan dan Saran}

Berdasarkan hasil penelitian dan pembahasan yang telah diuraikan, maka dapat diambil kesimpulan bahwa budaya organisasi memiliki peran terhadap disiplin kerja karyawan Direktorat Produksi PT Krakatau Steel (Persero) Tbk Cilegon yang ditunjukkan dengan naiknya koefisien regresi. Hasil penelitian ini menunjukkan bahwa sumbangan efektif $\left(\mathrm{R}^{2}\right)$ yang diberikan prediktor kepada kriterium adalah sebesar 0,285 atau setara dengan 28,5\% dengan taraf koefisien regresi sig $F$ Change sebesar 0,000 berdasarkan kaidah $\mathrm{p}<0,05$. Hal tersebut menunjukkan masih ada sekitar $71,5 \%$ faktor lain yang memberikan sumbangan efektif terhadap disiplin kerja.

Budaya organisasi berperan secara signifikan terhadap disiplin kerja karyawan Direktorat Produksi PT Krakatau Steel (Persero) Tbk yang ditunjukkan melalui nilai koefisien beta sebesar 0,534 dengan signifikansi korelasi prediktor (p) sebesar 0,000 berdasarkan kaidah $\mathrm{p}<0,05$. Hasil tersebut menunjukkan bahwa semakin 
tinggi budaya organisasi perusahaan yang diterapkan oleh karyawan memberikan pengaruh kepada semakin tingginya disiplin kerja karyawan

Adapun saran yang diajukan berdasarkan penelitian ini bagi peneliti selanjutnya agar dapat mengembangkan teori terkait disiplin kerja. Hal tersebut dikarenakan aspek disiplin kerja yang digunakan peneliti dalam penelitian ini masih terbatas pada tiga aspek yaitu sikap mental, pemahaman yang baik terhadap sistem maupun aturan dan sikap dalam berperilaku. Peneliti selanjutnya disarankan untuk memperdalam kajian terkait corporate values perusahaan, sehingga pengukuran terkait variabel budaya organisasi semakin sesuai dengan budaya organisasi perusahaan. Selain itu, penelitian selanjutnya diharapkan dapat mengkaji variabel-variabel lain yang berperan dalam membentuk disiplin kerja. Hal tersebut dikarenakan masih banyak faktor-faktor lain yang berperan dalam membentuk disiplin kerja karyawan. Sebagaimana penjelasan Helmi (1996) mengenai faktorfaktor yang mempengaruhi disiplin kerja yaitu faktor kepribadian seseorang dan faktor lingkungan.

\section{Daftar Pustaka}

Arikunto, S. (2010). Prosedur Penelitian. Jakarta: Rineka Cipta.

Azwar, S. (2011). Penyusunan Skala Psikologi. Yogyakarta: Pustaka Pelajar.

Brahmasari, I. A., \& Siregar, P.(2009). Pengaruh budaya organisasi, kepemimpinan situasional dan pola komunikasi terhadap disiplin kerja dan kinerja karyawan pada PT Central Proteinaprima TBK. Jurnal Aplikasi Manajemen, 7(1),238-250.

Daft, R. L. (2010). Management, $9^{\text {th }}$ Edition. Ohio: Cancage Learning.

Denison, D. R., \& Mishra, A. K. (1995). Toward a theory of organizatioal culture and effectiveness. International
Journal of Organization Science, 6(2), 204-223.

Franklin, A. L., \& Pagan, J. F. (2006). Organization culture as explanation for employee discipline practice. Review of Public Personnel Administration, 26(1), 52-73.

Gilberson, T. R., et al. (2009). Leadership and organizational culture: Linking CEO characteristics to cultural values. International Journal of Business Psychology, 24(1), 123-137.

Guffrey, C. J., \& Helms, M. M. (2001). Effective employee discipline: A case of the internal revenue service. Interational Journal of Public Personel Management, 30(1), 111-127.

Hasibuan, M.S.P. (2013). Manajemen Sumber Daya Manusia. Jakarta: Bumi Aksara.

Hayes, D. K., \& Ninemaier, J. D. (2009). Human Resources Management in the Hospitality Industry. New Jersey: John Wiley \& Sons, Inc.

Helmi, A.F. (1996). Disiplin kerja. Buletin Psikologi Universitas Gadjah Mada, 4(2). 32-42.

Krakatau Steel. Welcome to Krakatau Steel, Corporate Culture Our Company. Diakses pada 12 Maret 2015, dari Krakatau Steel (Persero) Tbk. Website: http://www.krakatausteel.com/ourcompany.index.html.

Kompas. MEA 2015 Berlaku, Indonesia Bakal diserbu Tenaga Kerja Asing. Diakses pada 24 Maret 2015, dari Kompas. Website: http://bisniskeuangan.kompas.com/rea d/2013/03/15/MEA.2015.Berlaku.Indo nesia.Bakal.Diserbu.Tenaga.Asing.htm 1.

Lateiner, A.R., Levine, I.E. (1985). Teknik Memimpin Pegawai dan Pekerja. Jakarta: Aksara Baru.

Lee, S. K. J., \& Yu, Kelvin. (2004). Corporate culture and organizational performance.International Journal of 
Management Psychology,19(4), 340359.

Moeljono, D. (2002). Pengaruh budaya korporat terhadap produktivitas pelayanan di PT Bank Rakyat Indonesia (Persero).(Universitas Gadjah Mada, 2002).

Munandar, A. S. (2008). Psikologi Industri dan Organisasi. Jakarta: UI-Press.

Nurwati, Palliati, A., Madjid, R., \& Nasrul. (2015).The influence of discipline and competency toward employee's performance. Journal of Education Psychology and Social Science: International Research Enthusiast Socety, 2423-1924.

Prijodarminto, S. (1993). Disiplin Kiat Menuju Sukses. Jakarta: Abadi.

PT Krakatau Steel (Persero) Tbk. (2009). Panduan Budaya Perusahaan. Cilegon: PT Krakatau Steel (Persero) Tbk.
Robbins, S. P. (2010). Management : $10^{\text {th }}$ Edition. Jakarta: Penerbit Erlangga.

Robbins, S. P. (2010). Organizational Behavior, $15^{\text {th }}$ Edition. New Jersey: Pearson Education, Inc.

Schein, E. H. (2004). Organizational Culture and Leadership, $3^{\text {th }}$ Edition. San Francisco: John Wiley \& Sons, Inc.

Sugiyono. (2007). Metode Penelitian Pendidikan Pendekatan Kuantitatif, Kualitatif, dan $R \& D$. Bandung: Alfabeta.

Suseno, M. N. (2012). Statistika Teori dan Aplikasi untuk Penelitian ilmu Sosial Humaniora.Yogyakarta: Ash-Shaff.

Wallace, J., Hunt, J., \&Richards, C. (1999). The relationship between organizational culture, organizational climate and managerial values.The International Journal of Public Sector Management, 12(7), 548-564. 
Psympathic, Jurnal Ilmiah Psikologi Desember 2016, Vol. 3, No. 2, Hal: 225 - 234 